\title{
The Cryopreservation of Euglena gracilis
}

\author{
By G. J. MORRIS AND CELIA E. CANNING \\ Institute of Terrestrial Ecology, Culture Centre of Algae and Protozoa, \\ 36 Storey's Way, Cambridge CB3 ODT
}

(Received 7 April 1978)

\begin{abstract}
A method for the cryopreservation of Euglena gracilis is described; for 26 strains the recovery on thawing was at least $30 \%$. Methanol $(10 \%, \mathrm{v} / \mathrm{v})$ was the only effective cryoprotectant for freezing to, and thawing from, $-196{ }^{\circ} \mathrm{C}$, though the recovery of cells depended on the rates of cooling and warming.
\end{abstract}

\section{INTRODUCTION}

Storage in liquid nitrogen is a standard method for the long-term maintenance of various cell types (Meryman, 1966). At this temperature $\left(-196^{\circ} \mathrm{C}\right)$ cell survival is independent of the period of storage and biological systems are genetically stable (AshwoodSmith \& Grant, 1977). Although many unicellular algae can be preserved with a recovery on thawing of greater than $60 \%$ (Morris, 1978), very low rates of survival have been reported for Euglena gracilis (Hwang \& Horneland, 1965). Some of the variables which determine the response of $E$. gracilis to freezing and thawing have now been studied and a method of cryopreservation has been developed for the many genetically unstable mutants of this organism (Schmidt \& Lyman, 1976) and for other strains of E. gracilis.

The importance of the interactions between the rate of cooling, cryoprotective additive and warming rate on the survival of plant cells has been stressed (Mazur, 1969). Hwang \& Horneland (1965) reported that E. gracilis suspended in glycerol $(10 \%, \mathrm{v} / \mathrm{v})$ survived better after 'slow' cooling $\left(1{ }^{\circ} \mathrm{C} \min ^{-1}\right.$ to $-30{ }^{\circ} \mathrm{C}$ followed by a plunge to $\left.-79{ }^{\circ} \mathrm{C}\right)$ than after 'fast' cooling (plunge to $-79^{\circ} \mathrm{C}$ ). In the present study, the effects of a number of potentially cryoprotective compounds on the response of $E$. gracilis to freezing and thawing were determined over a range of cooling and warming rates. From these data, a method of preservation was developed for one strain of E. gracilis and has been successfully applied to other strains of E. gracilis.

\section{METHODS}

Organism. Euglena gracilis CCAP strain 1224/5z was used to develop methods for preservation. Conical flasks (100 ml) containing $50 \mathrm{ml}$ liquid Eg medium (George, 1976) were inoculated with $1 \mathrm{ml}$ of a stationary phase culture (10 to $14 \mathrm{~d}$ ) and incubated at $20^{\circ} \mathrm{C}$ at a light intensity of 1100 lux on a cycle of $14 \mathrm{~h} \mathrm{light/}$ $10 \mathrm{~h}$ dark. In preliminary experiments, the effect of age of culture (1 to $21 \mathrm{~d})$ on the response to freezing and thawing was examined. Unless otherwise stated, cells from $7 \mathrm{~d}$ cultures were used.

Solutions. Additives (Table 1) were incorporated into Eg medium. Polyvinylpyrrolidone (PVP) of average molecular weight 40000 (Sigma) was used in solutions buffered with $N$-2-hydroxyethylpiperazine- $N^{\prime}-2$ ethanesulphonic acid (HEPES, 0.01 $\mathrm{m}$ ) and back-titrated with $\mathrm{KOH}$ to $\mathrm{pH} 7 \cdot 0$. All other solutions were unbuffered. Ethanol and methanol were sterilized by membrane filtration (Millipore, $0.4 \mu \mathrm{m}$ pore size): other solutions were autoclaved.

Freezing and thawing. Cells were used directly from liquid culture without any further preparation. The cell suspension $(1 \mathrm{ml})$ was placed in a $12 \times 35 \mathrm{~mm}$ sterile polypropylene tube (Sterilin). When additives were incorporated, $0.5 \mathrm{ml}$ of the cell suspension was added to $0.5 \mathrm{ml}$ of the additive solution to give the required final additive concentration. Cells were exposed to the additive for $15 \mathrm{~min}$ at $20^{\circ} \mathrm{C}$ before freezing. In 


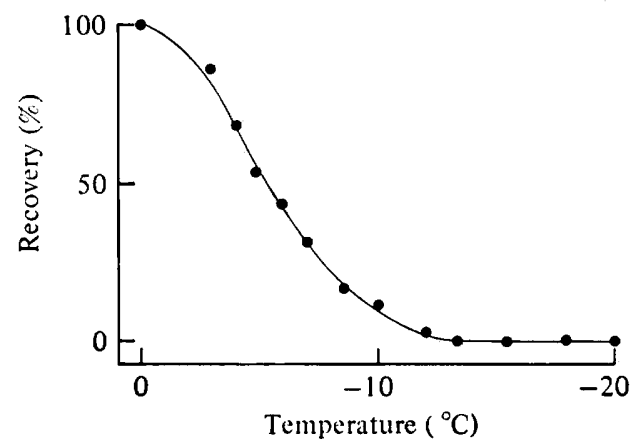

Fig. 1. Recovery (\%) of E. gracilis following cooling at $0 \cdot 25^{\circ} \mathrm{C} \mathrm{min}^{-1}$ to different final temperatures.

experiments to determine the concentrations of additives which were non-cytotoxic (recovery $>75 \%$ ) under these conditions, the additive concentration was reduced after $15 \mathrm{~min}$ exposure by rapid dilution $(1: 100)$ into fresh $\mathrm{Eg}$ medium.

Cell suspensions were frozen in liquid nitrogen either at a cooling rate of $0.25{ }^{\circ} \mathrm{C} \mathrm{min}^{-1}$ to different temperatures or at different cooling rates to $-196{ }^{\circ} \mathrm{C}$ using the method of Leibo et al. (1970). The rates of temperature change in every treatment were reccrded from a replicate sample using a copper-constantan thermocouple (28 SWG) connected to a Kipp-Zonen potentiometric recorder (model BD5). Cell suspensions were warmed by rapid agitation of the ampoule in a water bath at $35^{\circ} \mathrm{C}$ until the last visible crystals of ice had melted. Different rates of warming were obtained by the method of Thorpe et al. (1976).

Viability assay. Cell viability was assayed by the agar plate method of Morris (1976). Survival rates below $1.0 \%$ were recorded as zero. To compare the effectiveness of additives, the median lethal temperature $\left(\mathrm{LT}_{50}\right)$ was defined as the temperature at which $50 \%$ of the cells were lost during freezing and thawing under standard cooling and warming conditions.

Enzyme assay. Loss of membrane selective permeability following freezing and thawing was determined by measuring the release of the cytoplasmic enzyme malate dehydrogenase (MDH). The activity of MDH in cell-free supernatants and cell sonicates was assayed by the method of Bergmeyer \& Bernt (1974). The kinetics of MDH release from cells thawed from $-6{ }^{\circ} \mathrm{C}$ was examined at $20^{\circ} \mathrm{C}$ and the effect of different sub-zero temperatures on membrane integrity was determined $15 \mathrm{~min}$ after thawing. Enzyme loss to the supernatant was expressed as a percentage of the total intracellular enzyme activity.

\section{RESULTS}

\section{Freezing without additives}

At a rate of cooling of $0.25^{\circ} \mathrm{C} \mathrm{min}^{-1}$ the median lethal temperature for E. gracilis was $-5 \cdot 3{ }^{\circ} \mathrm{C}$ (Fig. 1). At all rates of cooling examined $\left(0 \cdot 1\right.$ to $\left.800{ }^{\circ} \mathrm{C} \mathrm{min}-1\right)$ the recovery of cells from $-196{ }^{\circ} \mathrm{C}$ was $<0.1 \%$. Cells from the early stages of culture ( 2 to $5 \mathrm{~d}$ ) were more sensitive to freezing injury than cells from older cultures (6 to $14 \mathrm{~d}$ ). The recovery of Escherichia coli (Toyokawa \& Hollander, 1956), Chlorella protothecoides (Morris, 1976) and ciliated protozoa (Simon \& Schneller, 1973; Osborne \& Lee, 1975) following freezing and thawing also varies with the age of culture.

Following freezing and thawing from $-6{ }^{\circ} \mathrm{C}$ there was a loss of MDH from the cells (Fig. 2), the amount of enzyme released increasing with the time of incubation after thawing. After freezing and thawing from temperatures above $-4{ }^{\circ} \mathrm{C}$ there was no significant loss of $\mathrm{MDH}$ (Fig. 3), but with lower temperatures, at which fewer cells survived (Fig. 1), $\mathrm{MDH}$ was released. Other workers have also observed that loss of cell viability following freezing and thawing is associated with damage to membranes (Mazur, 1970).

\section{Effects of cryoprotective additives}

The non-penetrating, low molecular weight additives (glucose, glycerol, sucrose) were more damaging than were penetrating (ethanol, methanol, dimethyl sulphoxide) or higher 


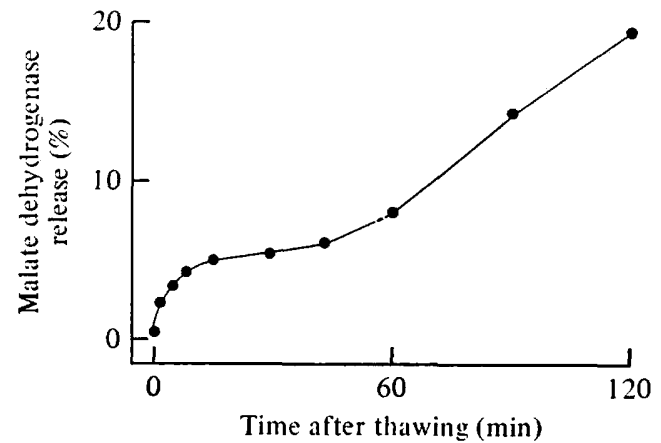

Fig. 2

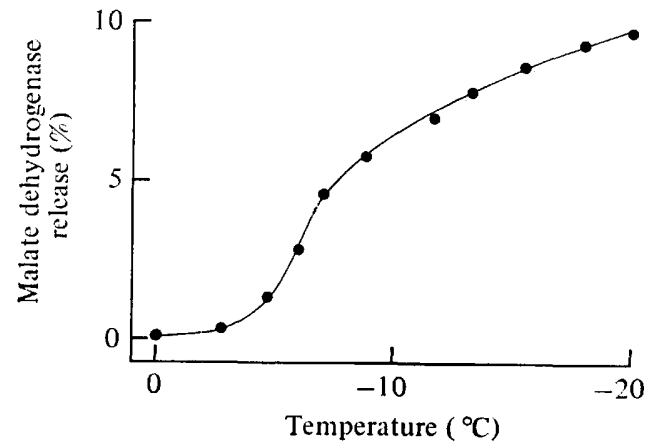

Fig. 3

Fig. 2. Release $(\%)$ of malate dehydrogenase from E. gracilis at different times following freezing to $-6{ }^{\circ} \mathrm{C}$ and thawing.

Fig. 3. Release (\%) of malate dehydrogenase from E. gracilis following cooling at $0 \cdot 25^{\circ} \mathrm{C} \min ^{-1}$ to different temperatures and thawing.

\section{Table 1. Median lethal temperatures for Euglena gracilis following freezing at $0.25{ }^{\circ} \mathrm{C} \mathrm{min}^{-1}$ in different additives}

The median lethal temperature $\left(\mathrm{LT}_{50}\right)$ was defined as that at which $50 \%$ of the cells were lost during freezing and thawing under standard cooling and warming conditions.

\begin{tabular}{lcc}
\multicolumn{1}{c}{ Additive } & Concentration & $\mathrm{LT}_{\mathbf{5 0}}\left({ }^{\circ} \mathrm{C}\right)$ \\
None & - & $-5 \cdot 3$ \\
Dimethyl sulphoxide & $10 \%(\mathrm{v} / \mathrm{v})$ & $-10 \cdot 2$ \\
Ethanol & $10 \%(\mathrm{v} / \mathrm{v})$ & -15 \\
Methanol & $10 \%(\mathrm{v} / \mathrm{v})$ & $<-50$ \\
Polyvinylpyrrolidone & $10 \%(\mathrm{w} / \mathrm{v})$ & $-4 \cdot 1$ \\
Sucrose & $7 \cdot 5 \%(\mathrm{w} / \mathrm{v})$ & $-4 \cdot 0$ \\
Glycerol & $5 \%(\mathrm{v} / \mathrm{v})$ & $-3 \cdot 4$ \\
Glucose & $5 \%(\mathrm{w} / \mathrm{v})$ & $-2 \cdot 8$
\end{tabular}

molecular weight (polyvinylpyrrolidone) additives. The concentrations of additives found to be non-cytotoxic ( $>75 \%$ recovery after $15 \mathrm{~min}$ at $20^{\circ} \mathrm{C}$ ) are shown in Table 1 . Hwang \& Horneland (1965) used glycerol as a cryoprotectant at a concentration of $10 \%(\mathrm{v} / \mathrm{v})$, but we found this to be cytotoxic: viability was only $20 \%$ after 15 min exposure at $20{ }^{\circ} \mathrm{C}$.

At a rate of cooling of $0.25^{\circ} \mathrm{C} \mathrm{min}-1$ the extracellular additives increased cellular injury, whilst the penetrating additives were protective (Table 1 ). The most effective cryoprotectant was methanol $(10 \%, \mathrm{v} / \mathrm{v})$ with an $\mathrm{LT}_{50}$ below $-50{ }^{\circ} \mathrm{C}$ at this rate of cooling. Viable cells were recovered from $-196{ }^{\circ} \mathrm{C}$ when methanol was used as a cryoprotectant (Fig. 4). The optimal rate of cooling was $0.34^{\circ} \mathrm{C} \mathrm{min}^{-1}$. A similar relationship between cell recovery and the rate of cooling has been observed for a number of cell types (Mazur, 1970). With all other additives there was no significant recovery of cells $(<0.1 \%)$ from $-196{ }^{\circ} \mathrm{C}$ at all rates of cooling examined. The recovery of cells cooled at $0.3{ }^{\circ} \mathrm{C} \mathrm{min}^{-1}$ in methanol $(10 \%$, $\mathrm{v} / \mathrm{v}$ ) was not affected by the rate of warming in the range 5 to $90^{\circ} \mathrm{C} \mathrm{min}^{-1}$ (Fig. 5). At rates of warming slower than $5{ }^{\circ} \mathrm{C} \mathrm{min}{ }^{-1}$ there was a reduction in cell viability.

\section{Cryopreservation of other strains of E. gracilis}

From the results presented, the best method for the routine cryopreservation of E. gracilis appeared to be as follows. To cells from $7 \mathrm{~d}$ cultures an equal volume of methanol $(20 \%$, $\mathrm{v} / \mathrm{v}$ ) was added. Following exposure for $15 \mathrm{~min}$ to the additive, the cells were cooled at a rate of $0.3{ }^{\circ} \mathrm{C} \mathrm{min}^{-1}$ to $-60{ }^{\circ} \mathrm{C}$ and then transferred into liquid nitrogen; thawing was at $90{ }^{\circ} \mathrm{C} \mathrm{min}-1$. With 26 strains of E. gracilis examined the recovery on thawing was greater than $30 \%$. 


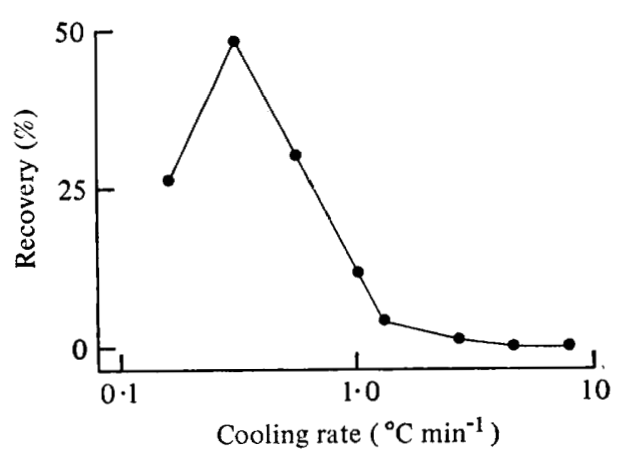

Fig. 4

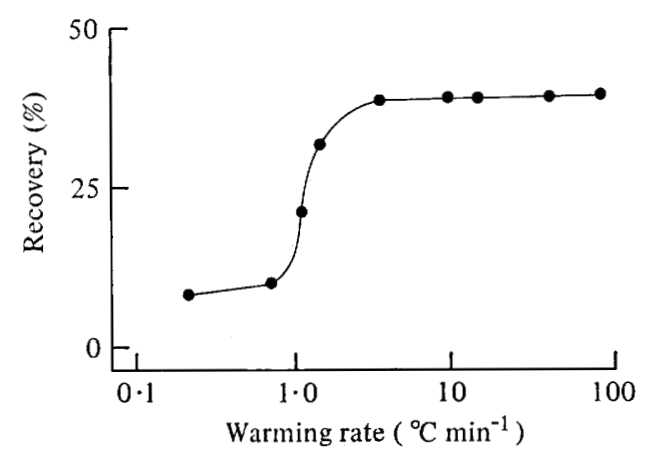

Fig. 5

Fig. 4. Recovery $(\%)$ of E. gracilis suspended in methanol $(10 \%, \mathrm{v} / \mathrm{v})$ after cooling at different rates to $-196^{\circ} \mathrm{C}$.

Fig. 5. Effect of the rate of warming from $-196^{\circ} \mathrm{C}$ on the recovery $(\%)$ of E. gracilis suspended in methanol $(10 \%, \mathrm{v} / \mathrm{v})$ and cooled at $0.3{ }^{\circ} \mathrm{C} \mathrm{min}^{-1}$ to $-196{ }^{\circ} \mathrm{C}$.

\section{DISCUSSION}

For storage at $-196{ }^{\circ} \mathrm{C}$, methanol was the only additive found to be protective for $E$. gracilis. Methanol is also cryoprotective for erythrocytes (Lovelock, 1954; Hudita, 1959; Meryman, 1968), tissue culture cells (Ashwood-Smith \& Lough, 1975) and Schistosoma spp. (James \& Farrant, 1976; 1977; James, 1977), but in these systems the conventional additives glycerol and dimethyl sulphoxide are also protective.

At slow rates of cooling large extracellular ice crystals form and this removal of water as ice produces hypertonic solutions to which the cells are exposed for relatively long periods during cooling; this leads to cellular dehydration (Mazur, 1970). In the absence of cryoprotective additives, exposure to the concentrated medium results in damage to the cellular membranes (Figs 2,3) and cell death (Fig. 1). At slow rates of cooling, exposure to concentrated extracellular additives was also found to be damaging (Table 1). The penetrating additives reduce the degree of cellular dehydration, but the actual extent of the shrinkage will be determined by the permeability of the additives into and out of the cells during freezing and thawing. It is possible that for E. gracilis the cryoprotective mechanism of methanol is associated with its rapid entry into and exit from the cells during cooling and warming. Ethanol and dimethyl sulphoxide are larger molecules which would not be expected to permeate as freely. Permeability studies of these additives to E. gracilis are now in progress. Methanol may also have a direct action on the membrane lipids, protecting them against freezing injury.

\section{REFERENCES}

Ashwood-Smith, M. J. \& Grant, E. (1977). Genetic stability in cellular systems stored in the frozen state. In The Freezing of Mammalian Embryos, pp. 251-268. Edited by K. Elliott \& J. Whelan. Amsterdam: Elsevier.

Ashwood-Smith, M. J. \& Lough, P. (1975). Cryoprotection of mammalian cells in tissue culture with methanol. Cryobiology 12, 517-518.

Bergmeyer, H. U. \& BerNT, E. (1974). Malate dehydrogenase. In Methods of Enzymatic Analysis, p. 613. Edited by H. U. Bergmeyer. New York and London: Academic Press.

GEORGE, E. A. (1976). List of Strains. Cambridge: Culture Centre of Algae and Protozoa.

HuditA, H. (1959). Studies on freezing and freeze- drying of blood, with special reference to the addition of alcohol. Low Temperature Science B17, 85-103.

HWANG, S. \& HoRneland, W. (1965). Survival of algal cultures after freezing by controlled and uncontrolled cooling. Cryobiology 1, 305-311.

JAMES, E. R. (1977). Interrelationships of cryoprotective additives and survival of frozen schistosomula. Transactions of the Royal Society of Tropical Medicine and Hygiene 71, 288.

JAMES, E. R. \& FARRANT, J. (1976). Studies on preservation of schistosomula of Schistosoma mansonii and $S$. mattheei. Cryobiology 13, 625630.

JAMES, E. R. \& FARRANT, J. (1977). Recovery of 
infective Schistosoma mansonii schistosomula from liquid nitrogen: a step towards storage of a live schistosomiasis vaccine. Transactions of the Royal Society of Tropical Medicine and Hygiene 71, 498-500.

Leibo, S. P., Farrant, J., Mazur, P., Hanna, H. G. \& SMiTH, L. H. (1970). Effects of freezing on marrow stem cell suspensions; interactions of cooling and warming rates in the presence of PVP, sucrose or glycerol. Cryobiology 6, 315-332.

LOVELOCK, J. E. (1954). The protective effect of neutral solutes against haemolysis by freezing and thawing. Biochemical Journal 56, 265-270.

MAZUR, P. (1969). Freezing injury in plants. Annual Review of Plant Physiology 20, 419-448.

MazUr, P. (1970). Cryobiology: the freezing of biological systems. Science 168, 939-949.

Meryman, H. T. (1966). Cryobiology. New York and London: Academic Press.

Meryman, H. T. (1968). Modified model for the mechanism of freezing injury in erythrocytes. Nature, London 218, 333-336.

Morris, G. J. (1976). The cryopreservation of Chlorella. 1. Interactions of rate of cooling, protective additive and warming rate. Archives of Microbiology 107, 57-62.
Morris, G. J. (1978). Cryopreservation of 250 strains of Chlorococcales by the method of twostep cooling. British Phycological Journal 13, 15-24.

Osborne, J. A. \& LeE, D. (1975). Studies on conditions required for optimum recovery of Tetrahymena pyriformis after freezing to and thawing from $-196^{\circ} \mathrm{C}$. Journal of Protozoology 22, 233 236.

SCHMidT, G. W. \& Lyman, H. (1976). Inheritance and synthesis of chloroplasts and mitochondria of Euglena gracilis. In The Genetics of Algae, pp. 257-299. Edited by R. A. Lewin. Oxford: Blackwell Scientific Publications.

Simon, E. M. \& Schneller, M. V. (1973). The preservation of ciliated protozoa at low temperatures. Cryobiology 10, 421-426.

ThorPe, P., KNight, S. K. \& Farrant, J. (1976). Optimal conditions for the preservation of mouse lymph node cells in liquid nitrogen using cooling rate techniques. Cryobiology 13, 126-133.

ToYokawa, K. \& HollandeR, D. H. (1956). Variation in sensitivity of Escherichia coli to freezing damage during the growth cycle. Proceedings of the Society for Experimental Biology and Medicine 92, 499-500. 